\title{
Značaj mladih protagonistov v Plavtovem Hišnem strahu in Trinovčevem
}

\section{Nada Grošelj*}

\section{UVOD}

Pogost motiv v rimski paliati, danes poznani predvsem po ohranjenih delih Plavta in Terencija, so medgeneracijski konflikti. Medtem ko očetje največkrat poudarjajo konvencionalno moralo in kažejo varčnost, že kar skoporitost, se sinovi v njihovi odsotnosti radi predajajo razvratu: zapravljajo denar, popivajo in se spuščajo v razmerja s heterami, ponavadi ob pomoči kakega nabritega domačega sužnja. Ker vlada v komediji saturnalijski narobe svet, na koncu »zmagajo « sinovi in sužnji, ki so tudi glavni junaki teh komedij. Tu in tam pa Plavt sinovom položi na jezik besede, ki odstopajo od njihovega siceršnjega ravnanja in jih prikažejo v odgovornejši luči. Njegova najrazvpiteje »moralistična« komedija je Trinovčevo (Trinummus), vendar zasledimo moralno navdahnjene vložke in značajske lastnosti tudi v drugi komediji s podobnim izhodiščem, ki deluje veliko bolj razposajeno: v Hišnem strahu (Mostellaria). V prispevku bomo obravnavali značaj mladih protagonistov, kakor se riše v teh dveh komedijah.

Komediji Hišni strah in Trinovčevo imata številne motivne vzporednice. V razvrstitvi Plavtovih iger po prevladujočem tipu komike, ki jo je predlagal italijanski klasični filolog Francesco Della Corte, obe sodita med pustolovske komedije, natančneje med pustolovske fantazijske komedije (commedia del romanzesco). ${ }^{1}$ Podobno kot burka, najpreprostejša plavtovska oblika, tudi fantazijska komedija gradi komiko na številnih burkaških elementih, vendar jo zaznamuje in prežema eksotični motiv potovanja, bodisi realističnega

* Društvo slovenskih književnih prevajalcev, Tomšičeva 12, Ljubljana, nada-marija.groselj@guest.arnes.si

1 Della Corte, Da Sarsina a Roma, 171-269. 
(zlasti trgovskega) bodisi fantazijskega. Čeprav potovanje nikoli ni prikazano na odru, je motor, ki poganja dejanje. Tako v Hišnem strahu kot v Trinovčevem se je pater familias že dolgo pred dramskim »zdaj« odpravil na trgovsko potovanje, doma pa pustil mladega sina (v Trinovčevem poleg sina še hčer) in služinčad. V obeh komedijah se sin med njegovo odsotnostjo predaja prijetnemu življenju in trati družinsko imetje. $\mathrm{V}$ obeh se oče nenapovedano vrne in doživi šok ob novici (ki se bo v Hišnem strahu izkazala za lažno in v Trinovčevem za ne povsem točno), da je sin med njegovo odsotnostjo prodal domačo hišo; v obeh se finančne zagate, ki jih je zakuhal sin, na koncu razrešijo s pomočjo zunanjih dejavnikov. V Hišnem strahu se kot deus ex machina pojavi sinov prijatelj in pivski kompanjon Kalidamat, ${ }^{2}$ ki smo ga v petem prizoru prvega dejanja in prvem prizoru drugega dejanja srečali mrtvo pijanega, in očetu obljubi povračilo vseh stroškov. V Trinovčevem pa vzroka za utemeljen preplah dejansko nikoli ni bilo, kajti oče ima v hiši skrit zaklad; skrbi družinskih članov in prijateljev, da je družina obubožala, so bile torej ves čas odveč in po začetni zmedi se vse pojasni in uredi.

Med komedijama so tudi vzporednice na mikroravni, denimo prispodoba hiše kot človeškega značaja ali stanja. Najbolj je razdelana v Hišnem strahu $84-156,{ }^{3}$ vendar se na kratko pojavi tudi drugod, denimo v Hišnem strahu 870-71 ali v Trinovčevem 323. Še en primer vzporednice na mikroravni je poskus domačega sužnja, da bi očeta ali kakega drugega starca odvrnil od družinske posesti - v Hišnem strahu od domače hiše, v Trinovčevem od njive - z zabavnim zatrjevanjem, da je ta kraj preklet in da v njem straši.

Za boljše razumevanje prispevka podajamo kratka povzetka obeh fabul. Hišni strah ima zelo preprosto zgodbo: atenski mladenič Filolah med odsotnostjo svojega dobičkolovskega očeta Teopropida obesi svoje prejšnje zgledno obnašanje na klin in se brez zadržkov prepusti zabavi, k čemur sodi tudi to, da se zaljubi v hetero Filematijo, jo odkupi in osvobodi. Pri tem ga podpira domači suženj Tranion, najbistrejši lik in dejanski junak igre. Ob novici o nenadejanem Teopropidovem prihodu zavlada panika, kajti pred hišo je pravkar v polnem teku popivanka, na kateri so Filolah s svojo ljubico Filematijo in njegov prijatelj Kalidamat s svojo Delfijo. Tranion jih vse imena po slovensko (Ljubljana: Modrijan, 1997). Kajetan Gantar v prevodu Hišnega strahu dejansko ohrani različice, ki so bližje izvirnim oblikam: »Kalidamates «, »Filolahes«, »Teopropides«, »Filematium«, »Delfium«, »Tranio«, »Grumio«. 
skupaj strpa v hišo, nato pa poskusi Teopropida odvrniti od vstopa z zgodbico, češ da se je $\mathrm{v}$ hiši pred leti zgodil umor in v njej straši. Zato naj bi se Filolah že pred meseci izselil v drug dom. A kaj, ko Teopropid novi dom seveda želi videti ... Skratka, komični zapleti in Tranionove improvizirane spletke se kar kopičijo, dokler prevara nazadnje ne pride na dan, toda po Kalidamatovem posredovanju se vse srečno izteče.

Zgodba Trinovčevega je nekoliko bolj zapletena. ${ }^{4} \mathrm{Na}$ začetku nastopita dva starca, Megaronid in Kalikles. Slednjemu je prijatelj Harmid, preden je odšel na trgovsko potovanje, zaupal v varstvo svoje imetje, sina Lezbonika in neimenovano hčer, zdaj pa je Megaronid prišel očitat Kaliklu, da je slabo opravil svojo nalogo varuha. Ne le, da je Lezbonik v očetovi odsotnosti spravil družino na kant, ampak je Kalikles od njega celo odkupil domačo hišo, tako da se je fant izselil v prizidek in obenem dobil finančno injekcijo za nove nezmernosti. Kalikles pojasni, zakaj je kupil hišo: pred odhodom mu je Harmid strogo zaupno pokazal, da ima v eni izmed spalnic zakopan zaklad, za katerega ne vesta niti njegova otroka. Ker je Lezbonik hišo zaradi gmotne stiske hotel prodati, Kalikles pa mu kot neodgovornemu razsipnežu ni hotel povedati za zaklad, je Kalikles rešil položaj tako, da jo je kupil kar sam, zaklad pa je tako ostal v lasti Harmidove družine. V nadaljevanju se Lezbonikov prijatelj Lizitel, potomec premožne in ugledne družine, ponudi, da bi se brez dote oženil z Lezbonikovo sestro (ki je ostala v domači hiši pri Kaliklu), toda Lezbonik o tem noče slišati. Pravzaprav je že takrat, ko ga prvič srečamo na odru, veliko zrelejši, kakor je bil v času blagostanja: zaradi financ je zelo zaskrbljen, predvsem pa je trdno odločen poskrbeti za sestrino doto, saj ne sme biti prikrajšana zaradi njega.

Sledi več komičnih spletk, v katerih sodelujejo zvesti družinski suženj Stazim kot avtor ene spletke, Megaronid kot idejni vodja druge spletke in najet slepar; prav slednji iznajde besedo »Trinovčevo" kot ime za današnji dan, ker se je v zameno za tri novce (tres nummi) zavezal, da bo sodeloval v Megaronidovi spletki in igral Harmidovega prijatelja. Medtem pride domov Harmid in sleparja $\mathrm{v}$ duhovitem drugem prizoru četrtega dejanja razkrinka, dobronamerni spletki Stazima in Megaronida pa propadeta, ker tako in tako nista več potrebni. Konec je predvidljiv: Lizitel se bo oženil z Lezbonikovo sestro, ki bo iz očetovega zaklada dobila bogato doto, oženil pa se bo tudi Lezbonik in s tem dokazal svojo novo zrelost. 


\section{ADULESCENS AMATOR V HIŠNEM STRAHU}

$\mathrm{V}$ obeh igrah torej nastopa mladenič, ki je krepko načel družinsko imetje. O Filolahu iz Hišnega strahu v prvem prizoru slišimo, da je bil "corruptum ex adulescente optumo« $(83),{ }^{5}$ dandanes, pravi domači suženj Grumion, vse dni in noči popiva in kroka, povrhu pa kupuje in osvobaja ljubice ter trati denar za pojedine (22-24). Še pred njegovim nastopom si torej gledalci ustvarijo podobo tipičnega komiškega mladeniča. V nadaljevanju se bo, kakor smo opisali zgoraj, po več plateh potrdila; $k$ seznamu Filolahovih ekscesov lahko dodamo tudi nespoštljive pripombe o očetu, ki seveda ne ustrezajo rimskemu občutku za pietas, na primer:

Siquidem hercle vendundust pater, venibit multo potius quam te me vivo umquam sinám egere aut mendicare.

(229-30)

Tako mi Herkula!

Če v revščini prodajati bi moral, rajši očeta rodnega prodam, kot da bi tebe [Filematijo] kdaj, dokler sem živ, pustil beračiti, živeti v bedi! ${ }^{6}$

Ali celo:

Utinam meus nunc mortuos pater ad me nuntietur,

ut ego exheredem me meis bonis fáciam atque haec sit heres.

$(233-34)$

O ko bi zdaj, ta hip, prišla novica,

da oče je umrl! Namesto sebe

takoj bi njo [Filematijo] za dedinjo določil! ${ }^{7}$

$\mathrm{V}$ takih dejanjih in besedah se torej potrjuje Filolahova vloga komiškega protagonista, ki se požvižga na družbene in moralne norme.

5 "Najboljši fant, pa se je spridil.«Hišni strah, 12, prev. Kajetan Gantar.

6 Ibid., 23.

7 Ibid., 23. 
Toda ko Filolaha prvič srečamo v živo, se ne predaja zabavi, temveč obžalovanju. V nenavadno temeljiti introspekciji primerja človeški značaj s hišo: oba propadeta, če nad njima ne bdijo graditelji oziroma starši. Sam pri sebi razčlenjuje, zakaj in kako je odpovedal kot »zlati mladenič«:

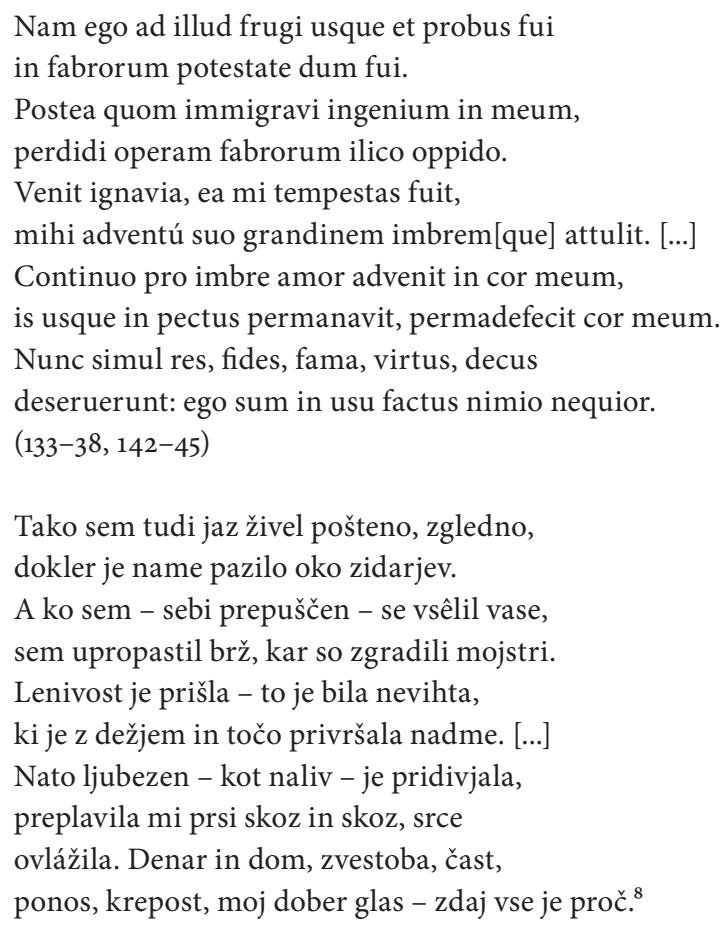

Ta razglabljanja Filolaha ne odvrnejo od zdajšnjega življenjskega sloga. Nasprotno, iz njih lahko črpa celo nekakšno potuho, ker si samega sebe zamišlja kot neživ predmet, pasiven in nezmožen nadzora nad samim sabo, torej kot subjekt, od katerega ni mogoče pričakovati odgovornosti za lastna dejanja. Kljub temu zasledimo melanholičen podton:

Cor dolet quom scio ut nunc sum atque ut fui, quo neque industrior de iuventute erat

[...] arte gymnastica:

disco, hastis, pila, cursu, armis, equo

victitabam volup, 
parsimonia et duritia discipulinae alieis eram, optumi quique expetebant a me doctrinam sibi.

Nunc, postquam nihili sum, id vero meopte ingenio repperi.

(149-56)

Srce je žalostno, ko vidi, kakšen sem

in kakšen bil sem prej, ko ni bilo vrstnika,

ki bi se $\mathrm{z}$ mano meril v ročnih spretnostih:

Nihče kot jaz ni vrgel diska, kopja, žoge,

nihče ni bil mi kos v borjenju, v ježi, v teku.

O zlati časi vzdržnosti in skromnosti,

ko bil sem drugim zgled svetal popolnosti!

Najboljši so me vsi kot vzor posnemali!

Zdaj nisem več za nič - in tega sam sem kriv! ${ }^{9}$

Povrhu je njegova zveza s Filematijo upodobljena $\mathrm{z}$ veliko simpatijo. Zgovorna je primerjava njunega razmerja $\mathrm{z}$ razmerjem med Menajhmom I in hetero Erotijo v drugi Plavtovi komediji, Dvojčka (Menaechmi): Menajhmus omeni Erotijo kot scortum (130) in v jezi tudi kot meretrix $(906,1048)$, sama pa vidi v njem zgolj eno svojih strank. Nasprotno sta Filolah in Filematija v Hišnem strahu očitno iskreno zaljubljena. O tem priča sámo dejstvo, da je Filolah svojo ljubico že pred začetkom dramskega dogajanja odkupil in osvobodil, potrdi pa se tudi $\mathrm{v}$ tretjem prizoru prvega dejanja, ko vsak od njiju dobi priložnost, da na samem (kot misli) spregovori o svojih čustvih do drugega. Po Filolahovi nastopni ariji namreč prideta iz hiše Filematija in njena služkinja Skafa; Filolah se skrije, iz skrivališča pa posluša njun pogovor in ga komentira. Filematija se s svojimi replikami izkaže za skrajno netipično komiško meretrix: medtem ko Erotija vidi v svojih ljubčkih zgolj sredstvo za zaslužek in strateško daje prednost najradodarnejšemu, je Filematija predana le Filolahu in osupljivo brezbrižna do denarja in praktičnih pomislekov. Njena čustva in njena moralna drža se nakažejo že na začetku prizora, kjer Skafi zatrdi, da se lišpa na ljubo Filolahu, »meo ocello, meo patrono« $(167),{ }^{10}$ in zavrne laskanje:

Ego verum amo, verum volo dici mi: mendacem odi. (181)

Resnico ljubim in sovražim laž, resnico hočem slišati. ${ }^{11}$ 
Njene neobičajne kvalitete se polno razkrijejo v nadaljevanju dialoga med njo in Skafo, v katerem jo praktična služkinja, po svojih besedah tudi sama nekdanja meretrix, nagovarja, naj se ne zaveže zgolj svojemu trenutnemu ljubimcu: resda jo je odkupil in osvobodil, a jo lahko kadarkoli zapusti nepreskrbljeno. Pragmatično gledano so ti opomini umestni, saj Filematija zaradi družbenih razlik med seboj in Filolahom ne more računati na poroko; če bi se oženil ali se je preprosto naveličal, bi se znašla na cesti, morda v starosti, ko bi ji bil onemogočen celo njen prejšnji način preživljanja. Toda na take opomine Filematija dosledno in idealistično odgovarja, da je treba ohraniti moralno integriteto, pa se bodo gmotni problemi že nekako razrešili:

Ut fama est homini, exin solet pecuniam invenire.

Ego si bonam famam mihi servasso, sat ero dives. (227-28)

Kakor gre o človeku dober glas,

tako si najde tudi svoj zaslužek.

Dovolj bogata bom, če le ohranim

dobro ime. ${ }^{12}$

Na Skafino vprašanje: „Quid illís futurum est ceteris qui té amant? « ${ }^{13}$ se odreže:

Magis amabunt,

quom me videbunt gratiam referre bene merenti. (231-32)

\author{
Samo še bolj \\ me vzljubijo, ko bodo videli, \\ kako hvaležna sem dobrotniku. ${ }^{14}$
}

Gre torej za argumentacijo, ki v Plavtovi komediji Stihus (Stichus, 144) ni prihranjena za meretrix, temveč za dve krepostni zakonski ženi iz višjega sloja, sestri, ki se kljub izginotju soprogov nočeta vnovič poročiti! Še vpadljivejša je vzporednica med nekdanjo sužnjo in hetero Filematijo in aristokratskima protagonistkama Stiha v poudarjanju občutka za dolžnost in lojalnosti, ki jo govorke po lastnem mnenju dolgujejo svojim moškim. V Stihu ena sestra opomni drugo: 
Ne quid magi' sit, omnibus obnixe opibus

nostrum officium meminisse decet. (45-46)

Nenehno si kličiva v misli,

kaj terja dolžnost, kajti to se spodobi. ${ }^{15}$

Prav tako mora po lastnih besedah tudi Filematija ne glede na to, da Filolahu zaupa in ga ljubi, vztrajati ob njem že iz hvaležnosti:

Eundem ánimum oportet nunc mihi esse gratum, ut impetravi, atque olim, priu' quam id extudi, quom illi subblandiebar. (220-21)

Zdaj, ko se mi je izpolníla želja, mu moram biti iz hvaležnosti naklonjena enako kot poprej, še preden sem srce mu omehčala. ${ }^{16}$

Skladno s Plavtovim prikazom njenega značaja se mora Filolahova zaljubljenost gledalcu zdeti razumljiva in upravičena. Ta zaljubljenost se kaže v množici zabavno impulzivnih opazk, ki jih daje iz svojega skrivališča; dve, v katerih podcenjevalno govori o očetu, smo že omenili. Čeprav se Filolah in Filematija v nadaljevanju posvetita novi pivski zabavi pred Filolahovo domačo hišo, v zavesti občinstva vendarle vztrajata njuna prva nastopa, v katerih se izkažeta za netipična predstavnika svoje zvrsti.

\section{ADULESCENS AMATOR VTRINOVČEVEM}

Filematija v Trinovčevem nima ustreznice, saj v tej komediji sploh ni ženskih vlog. O Lezboniku sicer slišimo, da je med drugim zapravljal denar za scorta (v množini; 412) in da je dal zaljubljenosti prednost pred vrlinami (648 in drugod), toda o njegovem razmerju ali razmerjih, zaradi katerih je zagazil v revščino, gledalec ne izve ničesar določnejšega, kar bi lahko omililo njegovo sodbo. ${ }^{17}$ Možna in zanimiva pa je primerjava med obema »izgubljenima sinovoma«, Filolahom iz Hišnega strahu in Lezbonikom iz Trinovčevega. Izhodiščni portret Lezbonika je še bolj problematičen od Filolaho- 
vega: v prologu alegorija Potrate - njene besede mora občinstvo kajpak razumeti kot verodostojne - pojasni, da je mladenič zafračkal domače imetje in da mu zato pošilja v hišo svojo hčer Revščino. Ta vtis se še okrepi s pripovedjo družinskega prijatelja Kalikla v drugem prizoru prvega dejanja, kajti medtem ko se je Filolahes strgal z vajeti šele takrat, ko je ostal prepuščen samemu sebi, je Lezbonik po Kaliklovih besedah znatno razredčil družinsko imetje že takrat, ko je bil oče še doma. Še več, oče je odrinil od doma po trgovskih poslih prav zato, da bi našel rešitev za spodjedene domače finance:

[N]am postquam hic eiius rem confregit filius videtque ipse ad paupertatem protractum esse se suamque filiam esse adultam virginem, simul eius matrem suamque uxorem mortuam, quoniam hinc iturust ipsus in Seleuciam, mihi commendavit virginem gnatam suam et rem suam omnem et illum corruptum filium. (108-14)

$[\mathrm{P}]$ otem ko mu je sin pognal imetje in je sprevidel, da je obubožal, da hčerka je odrasla, vendar samska, in njena mati - žena - je že mrtva, je, ker je bil namenjen v Selevkêjo, zaupal meni v varstvo svojo hčerko, imetje in še mladega capina. ${ }^{18}$

V očeh obeh starcev, Kalikla in Megaronida, Lezbonik vse od začetka do konca igre ostane malone neprišteven, vsekakor pa opravilno nesposoben mladostnik, ki bi storil karkoli, da pride do denarja za svoje orgije, in ki bo sredi dneva bržkone že pijan kot mavra:

\section{Denique}

diei tempus non vides? Quid illúm putas, natura illa atque ingenio? Iam dudum ebriust.

Quidvis probare poterit [...] (810-13)

Sploh pa,

ne vidiš, da je pozno? Kaj po tvojem počne tak mlad divjak? Je že nažehtan, na vse bo kimal. ${ }^{19}$

18 Tri pustolovske fantazijske komedije, 128.

19 Ibid., 170. 
Skratka, njegova podoba v očeh javnosti je porazna, dosti slabša od podobe Filolaha, v katerem suženj Grumion vidi nekdanjega zlatega fanta.

Toda ko Lezbonika v četrtem prizoru drugega dejanja prvič srečamo, naredi na nas zelo drugačen vtis. O pijanosti sredi dneva ni sledu; pravzaprav tesnobno sprašuje sužnja Stazima, kako je mogla kupnina za hišo skopneti v pičlih dveh tednih. Iz njunega pogovora izvemo, da so stroški res nastali tudi zaradi gostij in cip (406-12), toda cela četrtina kupnine je šla v veliko bolj nesebične namene: Lezbonik je prevzel jamstvo za nekega prijatelja in nato tudi plačal njegov dolg: "Nam nunc cum vidi miserum et me eius miseritumst." $(430)^{20}$ Pravzaprav njegov značaj najtočneje opiše njegov prijatelj Lizitel svojemu očetu Filtonu: bankrotiral je "per comitatem edepol, pater; praeterea aliquantum animi caussa in deliciis disperdidit«. $(333-34)^{21}$ Do takrat, ko se začne igra, se je že znatno streznil; zdaj je pobit in zaskrbljen zaradi domnevnega propada, $\mathrm{v}$ katerega je privedel družino in družinsko imetje. Muči ga misel na javno mnenje in zagrizeno je odločen preprečiti, da bi se njegova sestra omožila brez dote, torej kot drugorazredna nevesta. Kot zabrusi Lizitelu:

Meam ut sororem tibi dem suades sine dote. Aha! Non convenit me, qui abusus sum tantam rem patriam, porro in ditiis esse agrumque habere, egere illam autem, ut me merito oderit. Numquam erit alienis gravi' qui suis se concinnat levem. [...]

Nolo ego mihi te tam prospicere qui meam egestatem leves, sed ut inops infamis ne sim, ne mi hanc famam differant, me germanam meam sororem in concubinatum tibi, si sine dote $<$ dem $>$, dedisse magi' quam in matrimonium. Quis me inprobior perhibeatur esse? Haec famigeratio té honestet, me conlutulentet, si sine dote duxeris: tibi sit emolumentum honoris, mihi quod obiectent siet. (681-84, 688-94)

Praviš, naj ti sestro dam kar brez dote - o, pa ja! Ko imetje sem pognal, naj bi zdaj na mehkem spal, ona pa, oropana, bi me zasovrážila?

Kdor je brez vesti doma, med ljudmi nič ne velja. 


\section{[...]}

Nehaj tuhtati, kako bi mi lajšal revščino, raje misli na škandal, če ti jo brez dote dam. Saj se bo razširil glas, češ da sestro sem poslal $\mathrm{k}$ tebi kot priležnico, ne pa $\mathrm{v}$ zakon kot gospo. To bi se jim dal v zobe! Tebi bi bile, že res, čenče v čast, a moje ime bi bilo navadna smet, tvoj ugled bi se krepil, jaz bi v vseh očeh bil kriv. ${ }^{22}$

Za lik podivjanega sina v komediji je morda najpresenetljivejše, da iskreno pogreša očeta in si želi njegove vrnitve. Njegove zadnje besede v četrtem prizoru drugega dejanja so: »O pater, / enumquam aspiciam te?« (589-9o) ${ }^{23}$ Še več, ob vesti o njegovi vrnitvi sta tako on sam kot suženj Stazim iskreno navdušena, medtem ko je za Filolaha, ki se pravkar predaja popivanju pred domačo hišo, in za sužnja Traniona Teopropidova vrnitev povod za paniko. Iz gornje primerjave torej izhaja, da je Lezbonik v Trinovčevem skozi besede drugih likov prikazan neugodneje kot Filolah, vendar se je v skladu z bolj moralistično noto te komedije streznil že pred začetkom dramskega dejanja. ${ }^{24}$

\section{SODALIS OPITULATOR V HIŠNEM STRAHU IN TRINOVČEVEM}

Mlademu protagonistu komedije samoumevno pripada suženj, ki spletkari v njegov prid, prav tako samoumevno pa mu pripada tudi prijatelj, ki mu izrazito nesebično stoji ob strani in v nekaterih igrah dejansko reši položaj. V Hišnem strahu je tak prijatelj Kalidamat, v Trinovčevem pa Lizitel. V izrisu njunih likov še izraziteje izstopita burkaška nota Hišnega strahu in moralistični nadih Trinovčevega, vendar je v Hišnem strahu tudi prijateljeva (ne zgolj Filolahova) razpuščenost omiljena s simpatičnimi, celo občudovanja vrednimi lastnostmi.

Ko Kalidamata prvič srečamo v petem prizoru prvega dejanja, je v dosti slabšem stanju kot Filolah: sredi dneva se pijan opoteka po cesti in se opira na svojo ljubico Delfijo, komaj še sposoben govoriti:

\section{Callidamates}

$\mathrm{O}$ - o - ocellu's meus; 
tuos sum alumnus, mel meum.

DELPHIUM

Cave modo ne prius in via accumbas

quam illi, ubi lectust stratu', coimus.

CALlidamates

Sine, siné cadere me.

[...]

DELPHIUM

Si cades, non cades quin cadam tecum.

Callidamates

Iacentis tollet postea nos ambos aliquis. (325-30)

KALIDAMAT [Delfiji]

Ti si ze-zenica moja!

Jaz sem otroček tvoj, ti si moj med.

DELFIJA

Pazi, da prej ne obležiš na cesti

kot na blazinah, kamor greva zdaj!

KALIDAMAT

Pu-pusti, pusti me, naj padem!

[...]

DELFIJA

Če padeš ti, bom padla jaz s teboj!

KALIDAMAT

Nič hudega! Nas bo že kdo pobral! ${ }^{25}$

V nadaljevanju celo pozabi, kam sta namenjena:

CALLIDAMATES

Quo ego eam?

DelPHiUm

An $<$ ne $>$ scis?

CALLIDAMATES

Scio, in mentem venit modo: nemp' domum eo comissatum.

Delphium

Immo, istuc quidem.

Callidamates

Iam memini. (333-35a)

KALIDAMAT

Kam naj grem?

Hišni strah, 33-34. 
DELFIJA

Kaj ne veš?

KALIDAMAT

Aha, že vem,

zdaj mi je padlo v glavo: domov grem pit!

DELFIJA

$\mathrm{Ne}$, semle greva!

KALIDAMAT

Ah, zdaj sem se spomnil! ${ }^{26}$

Toda ko Kalidamat nastopi drugič, v tretjem prizoru petega dejanja, pokaže, da zna po potrebi prevzeti vlogo, ki jo od njega pričakuje družba, in nastopiti kot trezen, olikan, samoobvladan mlad mož iz boljše družbe. Uspešno zna zastopati sebe in prijatelja; še več, za Filolahovo zapravljanje prevzame svoj del odgovornosti in Teopropidu ponudi, da bo sam povrnil škodo, ki jo je domačemu proračunu prizadel Filolah:

Nunc te opsecro,

stultitiae adulescentiaeque éiius ignoscas: tuost;

scis solere illanc aetatem tali ludo ludere.

Quidquid fecit, nobiscum una fecit: nos deliquimus.

Faenus, sortem sumptumque omnem, quí amica <empta> est,

omnia

nos dabimus, nos conferemus, nostro sumptu, non tuo. (1156-61)

Zdaj te rotim: odpusti tej njegovi

mladostni zaletelosti! Tvoj sin je!

Sam dobro veš, da v teh neumnih letih

se fantje radi igrajo takšne igre.

Kar storil je, je storil v naši družbi.

Mi smo ga zapeljali, mi smo krivi.

Denar, obresti, stroške za dekle -

vse to bomo plačáli mi, vse to

bo šlo na naš in ne na tvoj račun. ${ }^{27}$

26 Ibid., 33-34.

27 Ibid., 132. 
Nasprotno je Lizitel, Kalidamatov ustreznik v Trinovčevem, poudarjen moralist in zato za nekatere (sodobne) bralce celo nekoliko odbijajoč. ${ }^{28} \mathrm{Ob}$ prvem nastopu odpoje dolgo arijo (223-75), v kateri - očitno z mislijo na Lezbonikov finančni in moralni brodolom - tehta, ali je v življenju boljši vodnik amor, ljubezen, ali res, premoženje. Ko razglablja o pogubnem vplivu »ljubezni«, zaradi katere zaljubljenec obuboža in začne zanemarjati javne dolžnosti, seveda ne misli na odnos med zaročencema ali zakoncema, ampak med hetero (meretrix) in njeno stranko, kar je jasno razvidno, denimo, iz verzov 250-51: »Nox datur: ducitur familia tota. ${ }^{29}$

Njegove prilizljivo moralistične odgovore očetu Filtonu v naslednjem prizoru sicer lahko razumemo kot način, s katerim hoče očetu izvabiti dovoljenje za poroko z Lezbonikovo sestro brez dote, toda njegove nabuhle pridige Lezboniku v verzih $641-78$ ne moremo odpisati kot retorično gesto:

Quid ais? Nam retineri nequeo quin dicam ea quae promeres: itan tandem hanc maiores famam tradiderunt tibi tui, ut virtute eorum ánteperta per flagitium perderes? Atque honori posterorum tuorum ut vindex fieres, tibi paterque avosque facilem fecit et planam viam ad quaerundum honorem: tu fecisti ut difficilis foret culpa maxume et desidia tuisque stultis moribus. Praeoptavísti amorem tuom uti virtuti praeponeres.

Nunc te hoc facto credis posse optegere errata? Aha! Non itast: cape sis virtutem animo et corde expelle desidiam tuo: in foro operam amicis da, ne in lecto amicae, ut solitus es. atque istum ego agrum tibi relinqui ób eam rem enixe expeto, ut tibi sit qui te corrigere possis, ne omnino inopiam cives obiectare possint tibi quos tu inimicos habes. [...]

At operam perire meam sic et te thaec dicta corde spernere $\dagger$

28 Prim. Anderson: »Lysiteles' entrance-speech [...] makes him declare priggishly for stolid bourgeois values« (»Plautus' 'Trinummus'«, 340); »Lysiteles [...] has been rigged by Plautus into a paragon of dull virtue« (ibid., 341). »[Ljubljena ženska] nakloni mu noč in s sabo privleče kompletno osebje.» Grošelj, Tri pustolovske fantazijske komedije, 136. Kot opozarja Erich Segal, »The Purpose of the Trinummus«, najdemo podobne misli v govoru, v katerem se je Katon starejši po Livijevih besedah (34.4.15-20) zavzemal za ohranitev Opijevega zakona, ki je omejeval žensko razkošje. Toda medtem ko Segal meni, da se Lizitelov opis nanaša na "women despoiling their husbands« (ibid., 263, op. 33), je iz gornjega navedka in drugih podrobnosti jasno razvidno, da Lizitel ne govori o zakonskih ženah kot Katon, temveč o meretrices. 
perpeti nequeo, simul me piget parum pudere te; et postremo, nisi mi auscultas atque hoc ut dico facis, tute pone te latebis facile, ne inveniat te Honor, in occulto iacebis quom te maxume clarum voles. Pernovi equidem, Lesbonice, ingenium tuom ingenuom admodum; scio te sponte non tuapte errasse, sed amorem tibi pectus opscurasse; atque ipse Amoris teneo omnis vias. $(641-54,660-67)$

Kakšne klatiš! Zdaj povem kar naravnost, kar ti gre: so ti predniki morda zapustili dober glas zgolj zato, da pogubiš plod vseh njihovih odlik? Da bi užival čast še rod poznih vnukov in otrok, sta ti oče in ded nekoč izgladila lep prehod do odlikovanj, a ti sam si si ga otežil zaradi lenarjenja in budalastih razvad; dal si zatrapanosti prednost pred vrlinami. Zdaj pa upaš, da boš skril stari greh? Kar misli si! $\mathrm{Ne}$, okleni se vrlin, daj slovo brezdelnosti, posle sklepaj s partnerji, ne $\mathrm{z}$ dekletom $\mathrm{v}$ postelji. Da ohraniš njivico, te spodbujam prav zato, da bi splaval kvišku sam in ti kak srdit meščan ne bi pomolil pod nos, češ da tolčeš revščino. [...]

Nočem, da bi ves moj trud in besede šli po zlu; za nameček ni mi všeč, da te bolj ne peče vest; in nazadnje, če boš gluh za moj sleherni poduk, boš za sabo skril svoj jaz in ne bo te našla Čast; ko si slave zaželiš, občemiš v obskurnosti. Dobro, Lezbonik, poznam žlahtnost tvojega duha. Ne zlohotnost, temveč strast ti je um zasenčila; sam prav dobro se spoznam na zvijače Amorja. ${ }^{30}$

Nenavaden je tudi njegov odnos do neveste, za katero se tako vneto poteguje, saj nikjer niti z besedo ne omeni, da bi ga pri snubitvi vodilo kaj drugega kot želja, da bi s poroko brez dote razbremenil prijatelja Lezbonika. Pa vendar je to, prvič, psihološko skrajno neverjetno, in drugič, deloma nepodprto s samimi dejstvi v igri, kajti pri tej poroki vztraja in izraža živo željo po njej celo v zadnjem prizoru, ko je že jasno, da Lezbonik in njegova družina nista v nikakršni denarni stiski: »Numquid caussaest quin uxorem cras do- 
mum ducam?« (1188) ${ }^{31}$ Vsaj v Plavtovem prikazu zgodbe, ki jo je sicer prevzel od grškega komediografa Filemona, je torej sodalis opitulator že kar parodija brezgrajnega prijatelja. Obenem pa ne moremo mimo dejstva, da so za rešitev Lezbonikove (namišljene) zagate vsa Lizitelova prizadevanja manj koristna od Kalidamatove gosposke poteze.

\section{ZAKLJUČEK}

Iz primerjave mladih protagonistov v Plavtovih komedijah Hišni strah in Trinovčevo se izlušči ugotovitev, da je slednja občutno bolj moralistična od prve, vendar po drugi strani tudi v Hišnem strahu ni mogoče videti gole burke kot, denimo, v Oslih (Asinaria) istega avtorja. Če si v Oslih oba protagonista, oče in sin, ki se pehata za isto meretrix, pravzaprav zaslužita zgolj posmeh občinstva, imajo glavni junak Hišnega strahu, njegov prijatelj in ljubica več značajskih lastnosti, ki so jih morale prikupiti tudi kritikom Katonovega kova.

\section{BIBLIOGRAFIJA}

Anderson, William S. »Plautus' 'Trinummus': The Absurdity of Officious Morality«. Traditio 35 (1979): 333-45.

Della Corte, Francesco. Da Sarsina a Roma: ricerche plautine. Druga, razširjena izdaja. Firence: La Nuova Italia, 1967.

Gantar, Kajetan, prev. Titus Maccius Plautus: Hišni strah. Iz antičnega sveta 14. Maribor: Obzorja, 1971.

Grošelj, Nada, prev. Tit Makij Plavt: Tri pustolovske fantazijske komedije. Dialog z antiko 32. Ljubljana: AMEU - ISH, 2018.

Leach, Eleanor Winsor. »De Exemplo Meo Ipse Aedificato: An Organizing Idea in the Mostellaria«. Hermes 97, št. 3 (1969): 318-32.

Lindsay, Wallace Martin, izd. T. Macci Plavti comoediae. Tomus I. Oxford: Clarendon Press, 1946 (prva izdaja 1904).

— . T. Macci Plavti comoediae. Tomus II. Oxford: Clarendon Press, 1940 (prva izdaja 1905).

Segal, Erich. »The Purpose of the Trinummus: For J. Arthur Hanson«. The American Journal of Philology 95, št. 3 (1974): 252-64.

Sharrock, Alison. »Reading Plautus' Trinummus: Who'd Bother? V: Plautine Trends: Studies in Plautine Comedy and its Reception, ur. I. N. Perysinakis in E. Karakasis, 167-95. Berlin/Boston: Walter de Gruyter $\mathrm{GmbH}, 2014$. 


\section{IZVLEČEK}

Pogost motiv v rimski paliati so medgeneracijski konflikti. Medtem ko očetje največkrat poudarjajo konvencionalno moralo in kažejo varčnost, že kar skoporitost, se sinovi v njihovi odsotnosti radi predajajo razvratu: zapravljajo denar, popivajo in se spuščajo v razmerja s heterami, ponavadi ob pomoči kakega nabritega domačega sužnja. Ker vlada v komediji saturnalijski narobe svet, na koncu "zmagajo« sinovi in sužnji, ki so tudi glavni junaki teh komedij. Tu in tam pa Plavt sinovom položi na jezik besede, ki odstopajo od njihovega siceršnjega ravnanja in jih prikažejo $\mathrm{v}$ odgovornejši luči. Njegova najrazvpitejša »moralistična« komedija je Trinovčevo (Trinummus), vendar zasledimo moralno navdahnjene vložke in značajske lastnosti tudi v drugi komediji s podobnim izhodiščem, ki deluje veliko bolj razposajeno: v Hišnem strahu (Mostellaria). Ob primerjavi mladih protagonistov v Plavtovih komedijah Hišni strah in Trinovčevo ugotovimo, da je komedija Trinovčevo občutno bolj moralistična od Hišnega strahu, vendar po drugi strani tudi v slednjem ni mogoče videti gole burke kot, denimo, v Oslih (Asinaria) istega avtorja. Če si v Oslih oba protagonista, oče in sin, ki se pehata za isto meretrix, pravzaprav zaslužita zgolj posmeh občinstva, imajo glavni junak Hišnega strahu, njegov prijatelj in ljubica več značajskih lastnosti, ki so jih morale prikupiti tudi kritikom Katonovega kova.

KLJUČNE BESEDE: rimska komedija, Plavtova komedija, dramski liki, morala 
THE CHARACTER OF THE YOUNG PROTAGONISTS IN PLAUTUS' MOSTELLARIA AND TRINUMMUS

\section{ABSTRACT}

A common motif in the Roman palliata is the conflict between generations. While the fathers usually uphold conventional morality and display frugality bordering on miserliness, the sons indulge themselves in their absence, squandering money, drinking, and consorting with meretrices, usually with the complicity of a clever family slave. Since the comedy genre depicts an upside-down, Saturnalian world, the final victory belongs to the son and slave as the comic protagonists. Now and then, however, the son is made to express an untypical sentiment which shows him in a more responsible light. Plautus' most notoriously 'moralising' comedy is Trinummus, but moralising passages and character traits may likewise be traced in another Plautine play starting from a similar situation, the much rowdier Mostellaria. A comparison between the young protagonists of Mostellaria and Trinummus reveals that while the latter play is indeed more inclined to moralise, not even the former can be regarded as a pure farce in the tradition of Asinaria. While the father and son of Asinaria, struggling for the same meretrix, seem to invite nothing but ridicule, the young protagonist of Mostellaria, his best friend, and his mistress display some character traits which should have found favour even with a Cato Censorius.

KEYWORDS: Roman comedy, Plautine comedy, dramatic characters, morality 